\title{
AGE AND GROWTH OF THE GOLDEN GREY MULLET LIZA AURATA (ACTINOPTERYGII: MUGILIFORMES: MUGILIDAE), IN THE MESSOLONGHI-ETOLIKO LAGOON AND THE ADJACENT GULF OF PATRAIKOS, WESTERN GREECE
}

\author{
George N. HOTOS* and George N. KATSELIS \\ Department of Aquaculture and Fisheries Management, Technological Educational Institute of Messolonghi, \\ 30200 Messolonghi, Greece
}

Hotos G.N., Katselis G.N. 2011. Age and growth of the golden grey mullet Liza aurata (Actinopterygii: Mugiliformes: Mugilidae), in the Messolonghi-Etoliko Lagoon and the adjacent Gulf of Patraikos, Western Greece. Acta Ichthyol. Piscat. 41 (3): 147-157.

Background. The fisheries of the Greek lagoons is based on the seasonal fish migration from coastal areas to the lagoon and the summer-to-winter offshore fish migration. The knowledge of the age and growth of the species in the two connected regions is essential for the proper management of the resources. The aim of this study was to estimate the age and growth of Liza aurata in the Messolonghi-Etoliko Lagoon system and the neighbouring coastal waters of the Gulf of Patraikos (Western Greece).

Materials and methods. From December 1992 to February 1994, a total of 1146 individuals of Liza aurata were caught in the Klisova Lagoon (part of the lagoon complex of Messolonghi-Etoliko) and their adjacent sea coastal area, using barrier fish traps, seine, and trammel nets. The fish age was determined from scale readings. Back calculated lengths at age, as derived using scales readings, were used to estimate the growth parameters of von Bertalanffy equation. The length-weight relation was estimated by the equation: $W=a \cdot L^{b}$.

Results. The total length $(L)$ of examined specimens ranged from 9.7 to $59 \mathrm{~cm}$. The scale readings revealed nine age classes in the Gulf of Patraikos ( 0 to VIII) and seven ( 0 to VI) in the lagoon. Maximum age was found to be 8 and 6 years for females and males, respectively. The analysis of the residuals sum of squares showed that the VBGF curves of sexes between the Patraikos sea area and the lagoon were not significantly different (sexes: $F=0.51, P>0.05$ and regions: $F=0.46, P>0.05$, respectively). The estimated values of VBGF for all samples were $L_{\infty}=65.08 \pm 2.61 \mathrm{~cm} ; k=0.149 \pm 0.017$ year $^{-1}$ and $t_{o}=-1.15 \pm 0.063$ year. No significant difference on the length-weight relations among the sexes was found $(F=3.15, P>0.05)$ while a significant difference on the length-weight relations among the regions (sea: $W=0.0036 L^{3.26}$; lagoon: $W=0.0057 L^{3.13}$ ) was found $(F=21.1$, $P<0.05)$ which reproduced a rather low difference $(< \pm 5 \%)$ along the size (weight) of species. The length-weight relations exhibited allometry.

Conclusion. The age and growth in length and weight of Liza aurata in the lagoon system of Messolonghi-Etoliko and the neighbouring seawaters of Gulf of Patraikos were not significantly different. This could be explained by the fact that the relative high salinity situation of the lagoon may rebut their high trophic advantage for the fish and/or alternatively, by a scenario that is based on the seasonal migrations of species between sea and lagoon.

Keywords: Golden grey mullet, Liza aurata, age, growth, western Greece, von Bertalnaffy estimates

\section{INTRODUCTION}

Grey mullets (Mugilidae) and mullet products have considerable economic importance at a regional level around the Mediterranean. In 1999, $48188 \mathrm{t}$ of grey mullets were produced by aquaculture in marine, brackish and inland waters of countries bordering the Mediterranean and the Black Sea (Anonymous 2002). Around the Mediterranean, an area of at least $6500 \mathrm{~km}^{2}$ of coastal lagoons (Pearce and Crivelli 1994) is exploited as fishing grounds (Ananiades 1984, Kapetsky 1984, Ardizzone et al. 1988, Peja et al. 1996, Anonymous 2001). Coastal lagoons and estuaries are key ecosystems and local fishers intensively exploit the increased natural productivity of these ecosystems (Kapetsky 1984).

The Greek lagoons cover an area of about $350 \mathrm{~km}^{2}$ and their exploitation is a common extensive culture, based on the seasonal migration from neighbouring coastal waters and entrance in the lagoons and the summer-to-winter offshore fish migration. The recorded annual fishery produc-

\footnotetext{
* Correspondence: Dr George N. Hotos, Department of Aquaculture and Fisheries Management; Technological Educational Institute (T.E.I.) of Messolonghi; 30200 Messolonghi, Greece, phone: +3026310 58252, fax.: +30 26310 58252; 58287, e-mail: ghotos@teimes.gr.
} 
tion of 50 Greek lagoons was estimated to about $1000 \mathrm{t}$, while $56 \%$ of this production consists of five species ( $\mathrm{Liza}$ aurata, Liza saliens, Liza ramada, Chelon labrosus, and Mugil cephalus) (Anonymous 2001).

One of the most important types of lagoon exploitation is the use of barrier traps to catch fish during their seasonal or ontogenic offshore migration. The fish traps operate from July to December. Before July, the traps are open allowing the entrance of fish into the lagoon. Also, other gear types such as gill nets and dip nets are also used in the lagoon all year long (Anonymous 2001). Thus, the knowledge of the biology and the behaviour of species in the two connected regions (sea and lagoon) are essential for their proper management.

The golden grey mullet, Liza aurata (Risso, 1810), is distributed around the Mediterranean, the Black Sea coast, along the Atlantic coast from Senegal to the southern coasts of Norway and Sweden, the British Isles (but not Baltic Sea), and the Caspian Sea where it has been introduced. Schools of the golden grey mullet occur mostly in shallow waters, especially in coastal lagoons of varying salinity while they enter rivers and estuaries for feeding. L. aurata spawns in the sea (Thomson 1990).

Information on golden grey mullet biology comes mainly from studies carried out in- and around the Mediterranean, Black and Caspian Sea and eastern Atlantic coasts (Brusle 1981, Quignard and Farrugio 1981). The information, however, on the biology of the golden grey mullet in the central and eastern Mediterranean - particularly in the Ionian and Aegean coasts (Greek and Turkish) - is limited to a number of papers (age, growth and sex ratio: İlkyaz et al. 2006; morphological characters of fry: Minos et al. 2002; seasonal occurrence of fry, spawning period: Katselis et al. 1994, Koutrakis et al. 1994, Hotos et al. 2000; description of seaward migration: Katselis et al. 2003, 2007; population dynamic: Katselis et al. 2010; scales suitability for age determination: Hotos 2003). Also, some studies presented information on the age and growth of this fish in the Ionian coasts (Giatnisi 1985, Konides et al. 1992) and the Gulf of Saronikos (Velentza unpublished*), but the estimates were of low accuracy.

The aim of this work was to determine the age and growth of the golden grey mullet in the MessolonghiEtoliko lagoons and the neighbouring shallow waters of the Gulf of Patraikos (Western Greece). The exploitation of the lagoonal system is based on the seasonal migration from the Gulf of Patraikos to the lagoons and the summerto-winter offshore fish migration. The fishes are captured by barrier traps, gill and dip nets (Katselis et al. 2003). The estimated total annual fish catches decreased from 1500-2000 $\mathrm{t}$ in the 1960s to 1300-1500 $\mathrm{t}$ in recent years (Kotsonias 1984, Dimitriou et al. 1994) and are derived from about 200 fishermen working at the barrier traps and 700 fishermen operating in the lagoon. The golden grey mullet consists of about $14.3 \%$ of the recorded annual fishery production (Katselis et al. 2003) with a rather great commercial value in the local market (4-6€ per kg, as of 2009). In view of the above, the knowledge of the age and growth of the species in two connected regions is essential for the proper management of the resources (Katselis et al. 2010).

\section{MATERIALS AND METHODS}

The lagoon system of Messolonghi-Etoliko is located in western Greece between lat $38^{\circ} 18^{\prime} \mathrm{N}$ to $38^{\circ} 30^{\prime} \mathrm{N}$ and long $21^{\circ} 08^{\prime} \mathrm{E}$ to $21^{\circ} 29^{\prime} \mathrm{E}$ and covers an area of approximately $150 \mathrm{~km}^{2}$ and is one of the largest lagoon systems in the Mediterranean (Fig. 1). Based on the topography, hydrology and fish species composition, six sub-areas can be defined (Dimitriou et al. 2000, Katselis et al. 2003). The largest portion (R3) is the Kentriki limnothalassa (Central lagoon) a shallow sea separated from the Gulf of Patraikos and the Ionian Sea by a chain of sand islands. To the north, the Etoliko Lagoon (R6) is connected to the Messolonghi Lagoon by a narrow "neck" and resembles a deep lake rather than a lagoon. The Klisova Lagoon (Fig. 1, R2), is a shallow, closed type lagoon communicating with the sea through 4 long canals. The temperature ranged from $11^{\circ} \mathrm{C}$ in February to $35.4^{\circ} \mathrm{C}$ in mid July, salinity fluctuated around 40 (\%o) while in isolated parts ranged from 2-3 (\%o) (on April after a rainfall) to 95 (\%o) in summer (Hotos and Avramidou 1997).

Sample: In total, 1146 individuals were examined. From these, 1065 specimens were caught monthly during December 1992-February 1994 in Klisova Lagoon using the barrier fish traps, seine and trammel nets. Also, 81 specimens were caught during January-September 1993 in the adjacent sea (Table 1) using seine and trammel nets with a rough selectivity for fish size over to $8 \mathrm{~cm}$. All golden grey mullets were iced-transferred to the laboratory where individuals were measured to the nearest $\mathrm{mm}$ for total length $(L)$, standard length $\left(L_{\mathrm{s}}\right)$, fork length $\left(L_{\mathrm{f}}\right)$, weighed (total weight) to the nearest $0.01 \mathrm{~g}$, and sexed. The sex and gonadal development were determined macroscopically using an eight stage key adapted from Kesteven (1960) and Hotos et al. (2000): I, immature; II, maturing; III, developing early; IV, developing late; V, gravid; VI, spawning; VII, Partial spent; VIII, spent.

The length-weight relation was estimated based on the equation: $W=\mathrm{a} \cdot L^{\mathrm{b}}$ where total weight $(W)$ is expressed in $\mathrm{g}$, and $L$ in $\mathrm{cm}$. Analysis of covariance (ANCOVA) was used for testing for statistically significant differences in length-weight relations between sexes and biotopes. Additionally, the Student's $t$-test (Zar 1984) was used to test for difference of the parameter $b$ from the theoretical value of 3 . Moreover, in order to assess the quantity of weight-length growth differences between the sexes, biotopes, as well as among the weight-length growth of species in the study area and other areas, the percentage difference in weight $(\% D W)$ was estimated:

$$
\% \mathrm{DW}_{i}=100 \cdot \frac{\left(\mathrm{W}_{i}-\mathrm{W}_{\text {all }}\right)}{\mathrm{W}_{\text {all }}}=100 \cdot \frac{\left(a_{i} L^{b i}-a L^{b}\right)}{a L^{b}}
$$

where $W_{\text {all }}$ is the estimated weight at length $L$ from all specimens in the present study, $W_{i}$ the estimated weight at length $L$ of sample $i(i=\operatorname{sex}$, biotopes, or regions) and $a, b$ the parameters of length-weight relation.

\footnotetext{
${ }^{*}$ Velentza A. 1992. Ilikia ke afxisi ton ixthion tis oikogeneias Mugilidae. [Age and growth of Mugilidae species.] BSc. Thesis, Aristotle University of Thessaloniki. [In Greek.]
} 


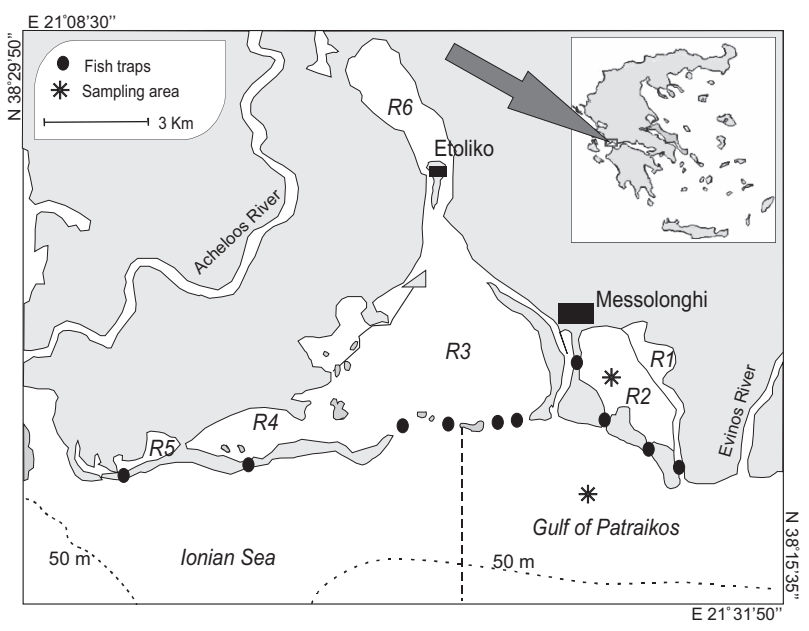

Fig. 1. Map of the Messolonghi Lagoon and the adjacent areas; $(\mathrm{R} 1=$ Anatoliki Klisova; $\mathrm{R} 2$ = Ditiki Klisova; $\mathrm{R} 3=$ Kentriki limnothalassa; R4 = Tholi; R5 = Paleopotamos; R6 = Etoliko Lagoon)

Scales were used for age determinations. The scales were removed from the second and third row just under the base of the first dorsal fin of the left side of fish. The scales were interpreted by use of standard criteria (Bagenal and Tesch 1978). Annual marks were distinct in both the anterior and lateral scale's field and displaced cutting-over of circuli in one or both lateral fields. The scales were examined two times by the same reader with a minimum of three weeks between examinations. When the readings of the same fish were different, the scales were considered unreadable.

In a previous study (Hotos 2003) the scales and scales' marks of the golden grey mullet have been described in much detail and they are generally clear and closely related to fish length and easily interpretable. Additionally, a strong linear relation between the scale size and the fish length was found as well as one mark was formed per year.

Back calculation of total lengths at annulus formation was done with Lee's method (Bagenal and Tesch 1978) which is a modified version of the direct proportion formula:

$$
L_{t}=L_{\infty}\left(1-e^{-k\left(t-t_{0}\right)}\right)
$$

where $R_{i}$ is the radius of the annulus $i, R_{c}$ is the total scale radius at time of capture, $L_{c}$ is the total length of the specimen at time of capture, $L_{i}$ is the estimated total length at the assigned age $i^{t h}$ and $a$ is the intercept on length axis from linear regression of length on scale radius.

Analysis of variance (ANOVA) was used to test for differences in the mean back-calculated total lengths-atannulus formation among ages, sexes and regions (lagoon, sea). Furthermore, the Tukey test was applied, to check which factors (ages, sexes, biotopes, fishing gears), differ from each other.

Estimates of theoretical growth in length were obtained by fitting the von Bertalanffy growth function (VBGF) to the mean back calculated total length-at age data. The VBGF is expressed as:

$$
L_{i}=a+\left(L_{c}-a\right) R_{i} R_{c}^{-1}
$$

in which $L_{\mathrm{t}}$ is length at age $t, L_{\infty}$ is the asymptotic length, $k$ is the growth coefficient, and $t_{0}$ is the age at which length is zero. Growth parameters were estimated iteratively by the nonlinear least squares estimation procedure, using the program SPSS ver.10. Growth curves were estimated separately for females and males and region and compared with the analysis of the residuals sum of squares (Chen et al. 1992).

Overall growth performance was estimated with the index $\varphi^{\prime}=\ln k+2 \ln L_{\infty}$, which allows the comparison of the overall growth performance between regions (study area and for other locations from the literature) (Pauly and Munro 1994).

\section{RESULTS}

During the study period a total of 1065 golden grey mullets were collected in the Klisova Lagoon and 81 in the Gulf of Patraikos (total 1146 individuals). The total length ranged from 9.7 to $59 \mathrm{~cm}$ (mean $=25.9 \mathrm{~cm}$; $\mathrm{SD}=7.2 \mathrm{~cm}$ ) while the total weight ranged from 7.4 to $1850 \mathrm{~g}$ (mean $=198.7 \mathrm{~g}$; SD $=203.3 \mathrm{~g}$ ). The regression equations between $L$ and $L_{\mathrm{S}}$ as well as $L$ and $L_{\mathrm{f}}$ had slopes that did not differ significantly between the sexes $(P>0.05)$. The relations for sexes combined were: $L=0.098+1.262 L_{\mathrm{S}}\left(R^{2}=0.98, n=1058\right.$, SEest (standard error of estimate) $=0.28$ ) and $L=-0.523+1.144 L_{\mathrm{f}}$ $\left(R^{2}=0.99, n=1035\right.$, SEest $\left.=0.32\right)$, respectively.

In the lagoon, 317 individuals were identified as male, 382 as female, and 366 as immature individuals (sex ratio males : females $\left.=1: 1.20 ; \chi^{2}=6.02 ; \mathrm{df}=1 ; P<0.05\right)$. In the Gulf of Patraikos, 28 individuals were identified as male, 41 as female, and 12 as immature individuals (sex ratio males : females $=1: 1.46 ; \chi^{2}=2.1 ; \mathrm{df}=1 ; P>0.05$ ) (Table 1). Fig. 2 shows the distribution of the gonadal development. The specimens caught in the Gulf of Patraikos were at an earlier maturity stage than those caught in the lagoon $\left(\chi^{2}=34.8 ; \mathrm{df}=7 ; P<0.05\right)$.

Table 1

Monthly samples of Liza aurata

\begin{tabular}{|c|c|c|c|c|c|c|c|c|}
\hline \multirow{2}{*}{ Year } & \multirow{2}{*}{ Month- } & \multicolumn{3}{|c|}{ Lagoon } & \multicolumn{3}{|c|}{ Gulf } & \multirow{2}{*}{ Total } \\
\hline & & IM & $\mathrm{F}$ & M & IM & $\mathrm{F}$ & M & \\
\hline 1992 & Dec & 10 & 4 & 3 & & & & 17 \\
\hline \multirow{12}{*}{1993} & Jan & 4 & 7 & 2 & 2 & & 4 & 19 \\
\hline & Feb & & 9 & 3 & & 4 & 3 & 19 \\
\hline & Mar & 4 & & & & & & 4 \\
\hline & Apr & 29 & 8 & 8 & 6 & 6 & 3 & 60 \\
\hline & May & 19 & 12 & 6 & 4 & & & 41 \\
\hline & Jun & 54 & 32 & 8 & & 7 & 7 & 108 \\
\hline & Jul & 23 & 36 & 14 & & 5 & 4 & 82 \\
\hline & Aug & 76 & 12 & 10 & & 12 & 3 & 113 \\
\hline & Sep & & 25 & 60 & & 7 & 4 & 96 \\
\hline & Oct & 67 & 148 & 155 & & & & 370 \\
\hline & Nov & 59 & 67 & 31 & & & & 157 \\
\hline & Dec & 18 & 14 & 13 & & & & 45 \\
\hline \multirow{3}{*}{1994} & Jan & 3 & 3 & 2 & & & & 8 \\
\hline & Feb & & 5 & 2 & & & & 7 \\
\hline & Total & 366 & 382 & 317 & 12 & 41 & 28 & 1146 \\
\hline \multicolumn{2}{|c|}{ Grand total* } & & 1065 & & & 81 & & 1146 \\
\hline
\end{tabular}
from Klisova Lagoon and Gulf of Patraikos

$\mathrm{IM}=$ immature, $\mathrm{F}=$ females, $\mathrm{M}=$ males; $*(\mathrm{IM}+\mathrm{F}+\mathrm{M})$. 
The parameter $b$ of length-weight relations was significantly different from $3(P<0.05)$ indicating allometry. ANCOVA on the log transformed values of length and weight showed no significant difference in the length-weight relations with $\operatorname{sex}(F=3.15, P>0.05)$. However, ANCOVA showed a significant difference $(F=21.1, P<0.05)$ in length-weight relations with region (sea: $W=0.0036 L^{3.26}$; lagoon: $W=0.0057 L^{3.13}$ ). The length-weight relation for all specimens was $W=0.0054 L^{3.15}\left(\mathrm{R}^{2}=0.99\right.$; SEest $\left.=0.086\right)$. Moreover, the percentage difference in weight $(\% \mathrm{DW})$ at weight range from 150 to $1600 \mathrm{~g}$ was $\pm 5 \%$ (Fig. 3 ).

From the total sample the scales were easy readable in $1066(93.02 \%)$ specimens while in $80(6.98 \%)$ specimens were considered unreadable (Table 2).

Scale readings showed nine age classes of which the first three (0, I, and II) were dominant and the last two (VII and VIII) were represented by very few female specimens (Table 2).

There were nine age classes of golden grey mullet in the Gulf of Patraikos while in the Klisova Lagoon only seven $(0-\mathrm{VI})$. The longest and oldest individual $(59 \mathrm{~cm}$, more of 8 years old) was caught in the sea while in the lagoon the longest and oldest individual was $47.1 \mathrm{~cm}$ and six years old.

The analysis of covariance showed no significant difference between male and female $L c \div R c$ relations $\left(F=4 \cdot 10^{-6}\right.$, $P>0.05)$. Thus, a pooled equation was estimated for the total sample: $L_{c}=4.17+6.063 R_{\mathrm{c}}, R^{2}=0.96$, SEest $=1.54$ (SEest is the standard error of estimation or of the slope).

Analysis of variance confirmed that for age groups I to IV there are significant differences on the back-calculated length at annulus formation among age groups $(P<0.05)$ while these differences (Tukey test) distributed rather randomly to the ages groups without any particular pattern (Table 3). On the other hand, no significant differences $(P>0.05)$ were found between the mean back-calculated length at annulus formation for males and females, for lagoon and sea as well as between the fishing gear types (Table 3).

Table 4 shows the parameters of the VBGF estimated by fitting the mean back-calculated length at annulus formation. The analysis of the residuals sum of squares showed that growth curves did not differ with sex and region (sexes: $F=0.51, P>0.05$; region: $F=0.46$, $P>0.05$ respectively). Thus, the VBGF parameters for all

The sample used for growth analysis of Liza aurata from Klisova Lagoon and Gulf of Patraikos

Table 2

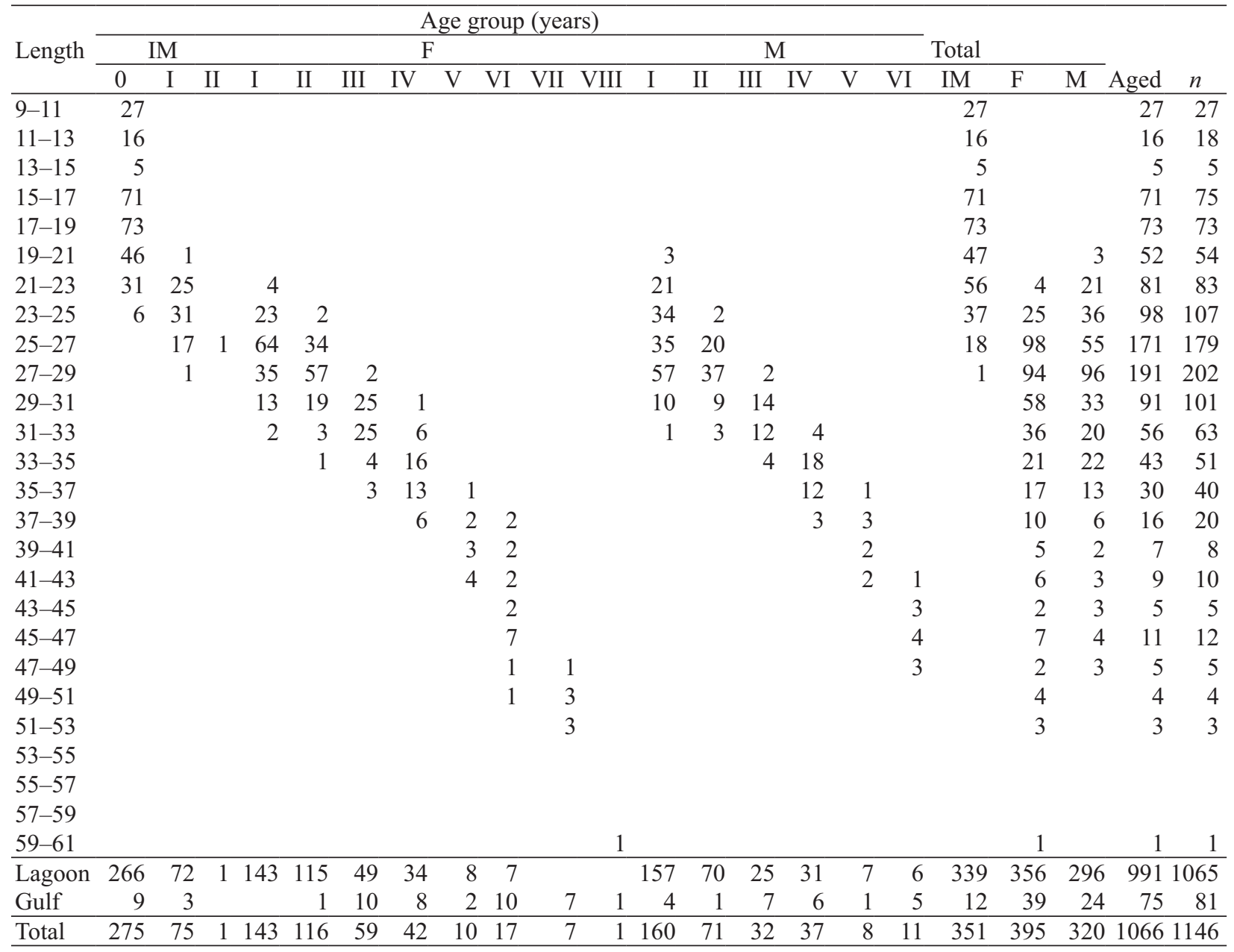

$\mathrm{IM}=$ immature, $\mathrm{F}=$ females, $\mathrm{M}=$ males, $n$, number of specimens used in scales ageing, $0=$ no annulus present on the scale. 


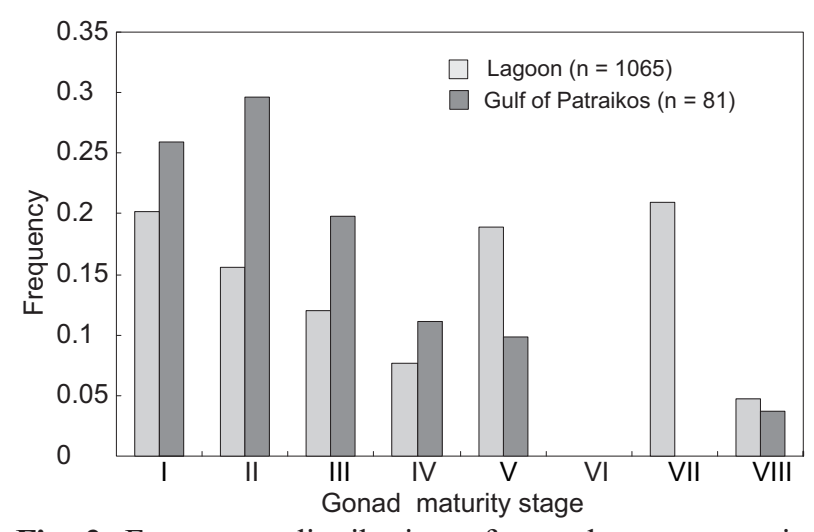

Fig. 2. Frequency distribution of gonad stage maturity (according to Kesteven 1960 and Hotos et al. 2000) of the males and females of Liza aurata from the Klisova Lagoon and the Gulf of Patraikos

samples combined $\left(L_{\infty}=65.08 \pm 2.61 \mathrm{~cm} ; k=0.149 \pm\right.$ 0.017 year $^{-1}$ and $t_{o}=-1.15 \pm 0.063$ years) were used to describe golden grey mullet's growth (Fig. 4). Back-calculated lengths at age were characterised by a large spread and overlapping among age groups.

The ratio of $L_{\mathrm{obs}} \div L_{\infty}$ ( $L_{\mathrm{obs}}$ is the maximum observed total length in the sample) was 0.72 in the lagoon and 0.90 in the sea. The estimation of $\varphi$ ' from the VBGF parameters from all samples combined was $\varphi^{\prime}=2.80$.

\section{DISCUSSION}

Various methods are used to determine the age in Mugilidae. Some authors using length frequency analysis (Albertini-Berhaut 1978, Drake et al. 1984a, Konides et al. 1992), but Quignard and Farrugio (1981) claim that these methods are useless for mullets because of the difficulties in obtaining samples and because spawning takes place over several months.

Both scales and otoliths are used for the age determination of Mugilidae. To use scales, otoliths or any other structure, for age determination, the deposition of regular detectable age marks is essential. Otolith age determination is supposed to be more accurate because otoliths have a higher priority in utilization of calcium (Carlander 1987). In mullet the otoliths have rarely been used because of the difficulty in reading the rings in the region near the focus of the otolith. Quignard and Farrugio (1981) indicated that only $67 \%, 66 \%$ and $64 \%$ of the otoliths of L. ramada, C. labrosus, and L. aurata respectively were readable. However, this difficulty can be overcome by smoothing the bezel side during the preparation of the otolith, increasing the percentage of reliability of readings up to $92.1 \%$ (Katselis et al. 2002) but with an increase in the otolith preparation cost.

The suitability of the scales for ageing of golden grey mullet has been reported. The scales and scale's marks of the golden grey mullet were generally clear and closely related to fish length, easily interpretable and a mark formed per year (February), while the first mark on the scales was

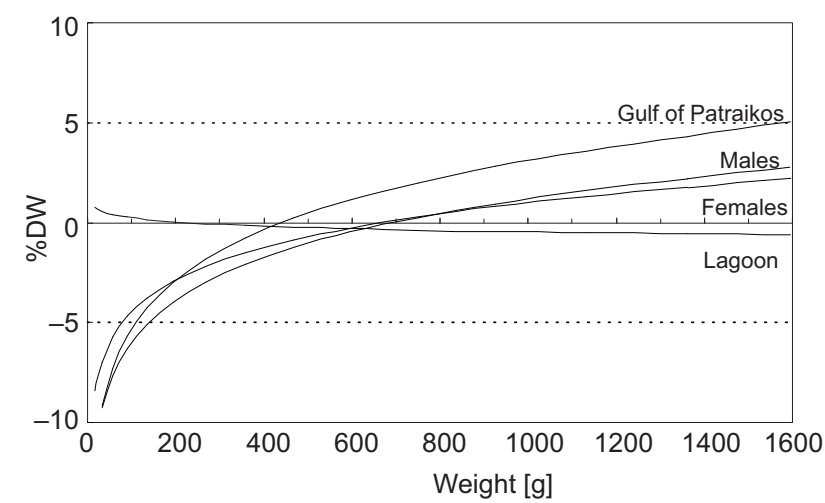

Fig. 3. Weight percentage difference $(\% \mathrm{DW})$ of sexes and biotopes of Liza aurata from the Klisova Lagoon and the Gulf of Patraikos, estimated by length-weight models in relation to the weight estimated from the corresponding model of pooled total sample

formed on fishes about 17 months old (Hotos 2003). Furthermore, they were generally clear and closely related to fish length $\left(R^{2}=0.96\right)$, easily interpretable with a high readability $(93 \%)$.

The oldest specimen of golden grey mullet in the Gulf of Patraikos was 8 years while in the lagoon it was 6 years. The golden grey mullet cannot be easily typified as a short-lived species, because in the present study several specimens older than 6 years were recorded. Indeed, Reay (1987) reports 14-year-old specimens from the Great Britain waters, while the oldest specimen was caught in Caspian Sea aged in 11-year-old (Fazli et al. 2008). On the other hand, the sea water preference of the oldest specimens of golden grey mullet is in agreement with the findings in other regions (Caspian Sea: Nikolskii 1954*; Black Sea, Bay of Biscay: Quignard and Farrugio 1981; Caspian Sea: Fazli et al. 2008; Adriatic Sea: Kraljević and Dulčić 1996), while the species has a shorter life span in internal waters (about 3-6 years) (Table 5).

The length overlapping between successive age classes is expected for species with an extended reproductive period. The golden grey mullet belongs to this group of species (Hotos et al. 2000). Moreover, the population of golden grey mullet caught in the lagoon system of Messolonghi-Etoliko consists of individuals of different ages, which inhabit several biotopes with various levels of trophic importance for fishes in adjacent areas of the Ionian Sea and the Gulf of Patraikos and enter into the lagoons each spring. This mechanism could explain a part of the variability of back calculated length at annulus formation among the ages (Table 3 ) and the length overlapping between successive age classes.

The equation of von Bertalanffy in the present study exhibited an excellent fit of the data $\left(R^{2}=0.92\right)$ and appeared to be an accurate description of growth in length of golden grey mullet for all stages of its life (fry, juveniles and adults). Indeed, the high values $L_{\mathrm{obs}} \div L_{\infty}\left(L_{\mathrm{obs}}\right.$ is the maximum observed length in the sample) ( 0.72 in the lagoon and 0.90 in the sea) indicated that the von Bertalanffy 
equation described a major part of species life. literature (Table 5). The overall growth performance index The $L c \div R c$ relation, also, exhibited an excellent fit of the $\varphi^{\prime}$ ranged from 2.52 to 2.99 . In the present study the index data $\left(R^{2}=0.96\right)$, while the intercept of their relationship $\varphi^{\prime}$ was estimated at 2.81 , but considered the confidence was $4.17 \mathrm{~cm}$ close to the length that appeared the scales interval $95 \%$ of VBGF parameters estimations $( \pm 1.96 \mathrm{SE})$ on body of species (Quignard and Farrugio 1981). Finally, (Table 4), can be estimated that the index $\varphi^{\prime}$ in the present the estimated value of $t_{0}$ was $-1.14 \pm 0.063$ years study ranged from 2.66 to 2.92 . In Table 5 seems that the (12.2-15.2 months) and can be considered, as the time most of index $\varphi^{\prime}$ records (63\%: 14 from 22 records) needed to form the first ring in scales (about 17 months) included in this range which it revealed a rather similar (Hotos 2003), indicated that the von Bertalanffy equation growth performance of species in study area compared to described, also, the growth of the young stages of species. other regions. However, some differences in the index $\varphi^{\prime}$ These finding are in agreement with the corresponding as well as in the back-calculated values of the total length value estimated for the $L$. saliens $\left(L_{\mathrm{obs}} \div L_{\infty}=0.88\right)$ in the at age from the present study, may be attributed either to Messolonghi-Etoliko Lagoon (Katselis et al. 2002).

A lot of variation in the values of the growth parame- ble false age estimation. Indeed, in some studies the ters of the golden grey mullet is evident from the published younger age groups were not collected (Kraljević and

Table 3

Mean back calculated total lengths $(\mathrm{cm})$ at annulus formation of Liza aurata from Klisova Lagoon and Gulf of Patraikos

\begin{tabular}{|c|c|c|c|c|c|c|c|c|c|}
\hline \multirow{2}{*}{$\begin{array}{l}\text { Age group } \\
\text { (yr) }\end{array}$} & \multicolumn{8}{|c|}{ Age group } & \multirow[b]{2}{*}{$n$} \\
\hline & I & II & III & IV & $\mathrm{V}$ & VI & VII & VIII & \\
\hline 0 & - & & & & & & & & 275 \\
\hline I & $18.51^{\mathrm{a}}$ & & & & & & & & 378 \\
\hline II & $17.53^{b}$ & $24.59^{\mathrm{d}}$ & & & & & & & 188 \\
\hline III & $15.80^{\mathrm{c}}$ & $24.27^{\mathrm{d}}$ & $29.88^{\mathrm{f}}$ & & & & & & 91 \\
\hline IV & $17.43^{b}$ & $24.67^{\mathrm{d}}$ & $29.35^{f}$ & $33.24^{\mathrm{i}}$ & & & & & 79 \\
\hline $\mathrm{V}$ & $17.96^{\mathrm{a}, \mathrm{b}}$ & $26.85^{\mathrm{e}}$ & $33.86^{\mathrm{h}}$ & $37.02^{\mathrm{k}}$ & $39.67^{1}$ & & & & 18 \\
\hline VI & $19.34^{\mathrm{a}}$ & $24.86^{\mathrm{d}}$ & $31.05^{\mathrm{g}, \mathrm{f}}$ & $34.66^{\mathrm{j}}$ & $39.37^{\mathrm{m}}$ & $41.95^{n}$ & & & 28 \\
\hline VII & $18.93^{\mathrm{a}, \mathrm{b}}$ & $24.02^{\mathrm{d}}$ & $30.00^{f}$ & $36.05^{\mathrm{j}}$ & $40.76^{1}$ & $43.44^{\circ}$ & 46.24 & & 7 \\
\hline VIII & 21.25 & 27.20 & 34.42 & 40.60 & 45.51 & 48.37 & 51.46 & 53.51 & 1 \\
\hline mean & 17.86 & 24.69 & 30.23 & 34.26 & 39.77 & 42.42 & 46.90 & 53.51 & \\
\hline $\mathrm{SD}$ & 2.02 & 2.11 & 2.66 & 2.82 & 2.13 & 2.20 & 2.14 & & \\
\hline$n_{r}$ & 683 & 412 & 224 & 133 & 54 & 36 & 8 & 1 & \\
\hline$F^{r}$ & 15.5 & 5.19 & 22.7 & 20.8 & 7.01 & 13.3 & & & \\
\hline$P$ & 0.00 & 0.00 & 0.00 & 0.00 & 0.00 & 0.00 & & & \\
\hline \multicolumn{10}{|c|}{ Per sex } \\
\hline Females & 17.79 & 24.86 & 30.38 & 34.37 & 39.60 & 42.25 & 46.90 & 53.51 & \\
\hline$n_{r}$ & 300 & 272 & 207 & 116 & 60 & 35 & 8 & 1 & \\
\hline$\stackrel{r}{\text { Males }}$ & 17.92 & 24.49 & 30.07 & 34.11 & 40.04 & 42.79 & & & \\
\hline$n_{r}$ & 355 & 313 & 229 & 124 & 49 & 11 & & & \\
\hline${ }_{F}^{r}$ & 0.65 & 2.99 & 0.87 & 0.39 & 0.54 & 0.45 & & & \\
\hline$P$ & 0.42 & 0.08 & 0.35 & 0.54 & 0.46 & 0.51 & & & \\
\hline \multicolumn{10}{|c|}{ Per region } \\
\hline Gulf (sea) & 17.82 & 24.68 & 30.13 & 34.31 & 39.83 & 42.53 & 46.90 & 53.51 & \\
\hline$n_{r}$ & 63 & 61 & 52 & 41 & 26 & 20 & 8 & 1 & \\
\hline Lagoon & 17.83 & 24.67 & 30.12 & 34.30 & 39.82 & 42.44 & & & \\
\hline$n_{r}$ & 727 & 351 & 172 & 92 & 28 & 16 & & & \\
\hline$F^{r}$ & 0.07 & 0.08 & 0.02 & 0.02 & 0.04 & 0.01 & & & \\
\hline$P$ & 0.81 & 0.78 & 0.87 & 0.96 & 0.84 & 0.91 & & & \\
\hline \multicolumn{10}{|c|}{ Per fishing gear } \\
\hline Barrier traps & 17.83 & 24.68 & 30.10 & 34.30 & 39.85 & 42.45 & & & \\
\hline$n_{r}$ & 651 & 281 & 107 & 55 & 9 & 4 & & & \\
\hline$\stackrel{r}{\text { Net Lagoon }}$ & 17.80 & 24.65 & 30.15 & 34.29 & 39.80 & 42.43 & & & \\
\hline$n_{r}$ & 76 & 70 & 65 & 37 & 19 & 12 & & & \\
\hline Net Sea & 17.81 & 24.68 & 30.18 & 34.31 & 39.83 & 42.53 & 46.90 & 53.51 & \\
\hline$n_{r}$ & 63 & 61 & 52 & 41 & 26 & 20 & 8 & 1 & \\
\hline$F^{r}$ & 0.01 & 0.11 & 0.02 & 0.04 & 0.03 & 0.04 & & & \\
\hline$P$ & 0.99 & 0.89 & 0.98 & 0.95 & 0.96 & 0.95 & & & \\
\hline
\end{tabular}

$n=$ number of specimens, $n_{r}=$ number of scales readings, $\mathrm{SD}=$ standard deviation, $F=F$-ratio; $P=$ significance level; The same superscript letters mark back-calculated lengths showing non significant differences between the age groups. 
Table 4 in shallow inshore waters, where the temperature is influ-

Parameters of the von Bertalanffy equation for Liza aurata from Klisova Lagoon and Gulf of Patraikos (with standard error in the brackets)

\begin{tabular}{|c|c|c|c|c|c|}
\hline & $\mathrm{F}$ & M & Lagoon & Gulf (sea) & All \\
\hline$L_{\infty}[\mathrm{cm}]$ & $\begin{array}{l}63.12 \\
(2.86)\end{array}$ & $\begin{array}{l}64.98 \\
(3.7)\end{array}$ & $\begin{array}{l}64.12 \\
(3.8)\end{array}$ & $\begin{array}{l}66.15 \\
(4.16)\end{array}$ & $\begin{array}{l}65.08 \\
(2.61)\end{array}$ \\
\hline$k\left[\right.$ year $\left.^{-1}\right]$ & $\begin{array}{l}-0.159 \\
(0.013)\end{array}$ & $\begin{array}{l}-0.149 \\
(0.019)\end{array}$ & $\begin{array}{l}-0.152 \\
(0.016)\end{array}$ & $\begin{array}{l}-0.145 \\
(0.017)\end{array}$ & $\begin{array}{l}-0.149 \\
(0.010)\end{array}$ \\
\hline$t_{o}$ [year] & $\begin{array}{l}-1.094 \\
(0.081)\end{array}$ & $\begin{array}{l}-1.148 \\
(0.100)\end{array}$ & $\begin{array}{l}-1.140 \\
(0.080)\end{array}$ & $\begin{array}{l}-1.170 \\
(0.013)\end{array}$ & $\begin{array}{l}-1.141 \\
(0.063)\end{array}$ \\
\hline SEest & 4.66 & 4.51 & 4.6 & 3.65 & 4.55 \\
\hline \multirow[t]{2}{*}{$R^{2}$} & 0.92 & 0.91 & 0.89 & 0.95 & 0.92 \\
\hline & & & \multicolumn{2}{|c|}{$F=0.46 ; P=0.70$} & \\
\hline
\end{tabular}

$\mathrm{F}=$ females, $\mathrm{M}=$ males, $\mathrm{All}=$ pooled sample; $L_{\infty}=$ asymptotic length; $k=$ growth coefficient; $t_{o}=$ age at which length is zero; SEest $=$ Standard Error of Estimation; $R^{2}=$ Coefficient of determination; $F=F$-ratio, $P=$ significance level.

Dulčić 1996: $\varphi^{\prime}=2.52$ ) and in some others fish older than two or three years were not recorded (Serbetis*1939: $\varphi^{\prime}=2.99$ and Heldt ${ }^{*}$ 1948: $\varphi^{\prime}=2.89$; Arruda et al. 1991: $\left.\varphi^{\prime}=2.71\right)$. Also, in previous studies in western Greece coastal waters (Konides et al. 1992, Giatnisi unpublished ${ }^{* *}$ ) the $\varphi^{\prime}$ values (2.64 and 2.65 respectively) were close to the lower limit of estimated $\varphi^{\prime}$ in the present study. This fact may be a result of the low accuracy of age estimation and can be attributed on the unsuitability of length frequency as an age estimation method for mullet as used by Konides et al. (1991) and on the fact that the age has been estimated from a sample of young specimens (0-3 age groups) (Giatnisi unpublished ${ }^{* *}$ ).

Certainly, different growth rates of golden grey mullet in different locations are probably due to local differences on important factors influencing growth, like water temperature. This is because grey mullets spent most of their time

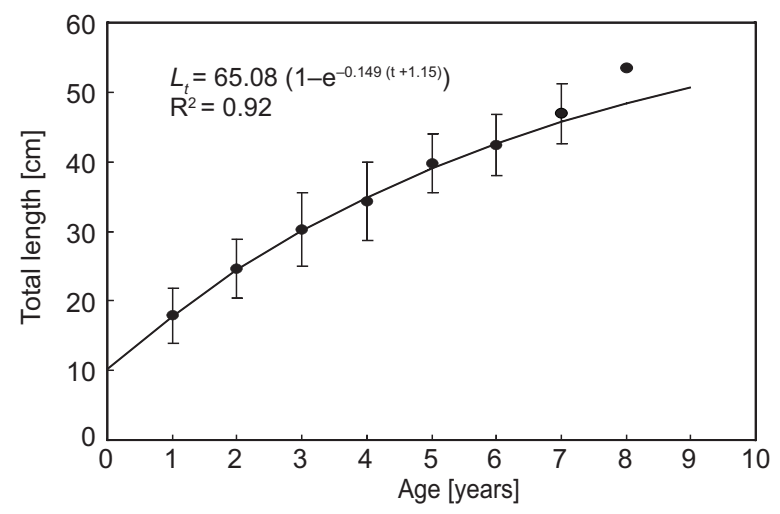

Fig. 4. Von Bertalanffy growth curve for both sexes of Liza aurata from the Klisova Lagoon and the Gulf of Patraikos (combined data); Solid dots are the mean back calculated lengths at annulus formation and bars indicate two folds of the SD enced more by local conditions (with noticeable fluctuations from location to location) than by temperature of the open sea, which is more stable (Kennedy and Fitzmaurice 1969). However, the different growth rates of golden grey mullet in different locations can be related to other factors apart from temperature, such as food availability and/or densitydependent relations (El Zarka et al. 1970, Drake et al. 1984 b).

Growth in length was similar for males and females, even though females were predominant in the older age groups (Table 3). Although it is not clear if differences in the growth between the sexes in mullet species are existing, when these are noticeable the females grow faster than males while these appear only after the second year of life (Quignard and Farrugio 1981). However, the findings for other Mugilidae species in the Greek lagoons (Messolonghi-Etoliko Lagoon: L. ramada: Minos unpublished ${ }^{* * *}$; L. saliens: Katselis et al. 2002; Porto Lagos Lagoon and Vistonis Lake: L. ramada, L. saliens and C. labrosus: Koutrakis and Sinis 1994) supported the similarity of growth in length between sexes.

The parameters $b$ of the length-weight relation show that golden grey mullet in the study area grew allometrically while it was greater than in other regions (Table 6). Variability on L-W estimates could be attributed to a number of other factors including season, habitat, gonad maturity, sex, diet and stomach fullness, health, preservation techniques and differences in the observed length ranges of the specimen caught (Froese 2006). Thus, in the present study the differences on the parameters of length-weight relation between the sea and lagoon samples can be attributed to the corresponding differences on the stage maturity of samples (Fig. 2), as well as to the season of samples collected. Indeed, the sea sample was collected during the period from January to September while more than of $50 \%$ of specimens of lagoon sample were collected during the period October to December (Table 1). However, the percentage differences on weight between the sea and the lagoon, in the range of weight $150-1600 \mathrm{~g}$, are low (about $\pm 5 \%$ ) (Fig. 3 ). In contrast, the corresponding differences on weight between the present study and other regions (Fig. 5) are ranged from $\pm 5 \%$ (Aveiro Lagoon: Arruda et al. 1991; Homa Lagoon: İlkyaz et al. 2006; Coasts of W. Greece: Konides et al. 1992) to $-60 \%$ (Brittany, France: Quignard and Farrugio 1981) and to $80 \%$ (Étang de Berre, France: Quignard and Farrugio 1981).

In conclusion, the results of the present study revealed that the age and growth in length and weight of golden grey mullet in the Klisova Lagoon and in the adjacent coastal waters of the Gulf of Patraikos were not significantly different. Taking into account that, the trophic level of the Klisova Lagoon is higher than that of the sea (Hotos and Avramidou 1997), it would be expected to see differences in the growth of the grey mullet between the two biotopes. However, the growth performance and the osmotic adjustment effort of golden grey mullet are opti-

${ }^{* *}$ Giatnisi M.E. 1985. Sigritiki meleti ton viologikon parametron tou genus Mugil (Family: Mugilidae). [Comparative study of biological parameters of genus Mugil (Family: Mugilidae).] MSc Thesis, University of Athens. [In Greek.]

${ }^{* * *}$ Minos G. 1996. Viologia ke dinamiki tou ihthios Liza ramada (Risso, 1810) (Pisces:Mugilidae) sti limnothalassa Messolonghiou-Etolikou. [Biology and population dynamics of the thin-lipped grey mullet Liza ramada (Risso, 1810) (Pisces:Mugilidae) in the lagoon of Messolonghi-Etoliko.] Thesis, University of Patras. [In Greek.]
} 


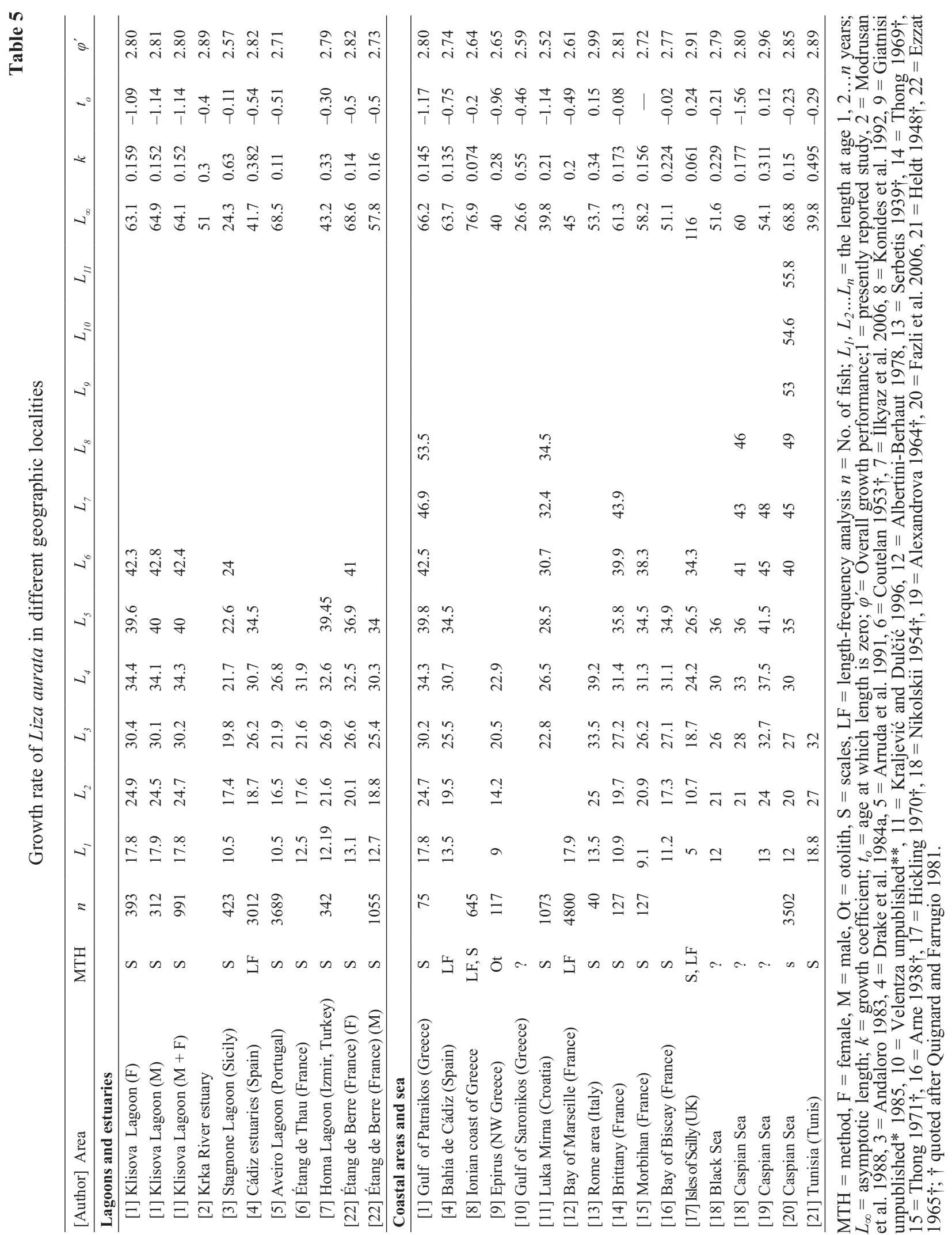


Table 6

Length-weight relation (a, b) of Liza aurata in this study and in studies reported by other authors

\begin{tabular}{|c|c|c|c|c|c|c|}
\hline Area & Author(s) & $\begin{array}{c}\text { Type } \\
\text { of length }\end{array}$ & $\begin{array}{c}\text { Length } \\
{[\mathrm{cm}]}\end{array}$ & $n$ & $\mathrm{a}$ & b \\
\hline Ionian coast of Greece & Konides et al. 1992 & $L_{f}$ & $6-26$ & 645 & $2.8 \cdot 10^{-2}$ & 2.78 \\
\hline Gulf of Patraikos $(M+F)$ & Present study & $\stackrel{f}{L}$ & $18-59$ & 81 & $3.6 \cdot 10^{-3}$ & 3.26 \\
\hline Klisova Lagoon $(\mathrm{M}+\mathrm{F})$ & Present study & $L$ & $9.7-47$ & 1065 & $5.7 \cdot 10^{-3}$ & 3.13 \\
\hline Epirus (NW Greece) & Giatnisi unpublished $^{1^{*}}$ & $L$ & $9-25$ & 117 & $3.8 \cdot 10^{-3}$ & 3.20 \\
\hline Gulf of Saronikos (Greece) & Velentza unpublished $^{2}$ & $L_{s}$ & $15.5-21$ & & $7.8 \cdot 10^{-3}$ & 3.23 \\
\hline Luka Mirna (Croatia) & Dulčić and Kraljević 1997 & & $15-39$ & & $9.1 \cdot 10^{-3}$ & 2.95 \\
\hline Bay of Marseille (France) & Albertini-Berhaut 1978 & $L$ & $1-19$ & 4800 & $4.6 \cdot 10^{-3}$ & 3.31 \\
\hline Étang de Berre (France) (F) & Ezzat $1965 \dagger$ & $L$ & $9-42$ & & $1.5 \cdot 10^{-2}$ & 2.49 \\
\hline Étang de Berre (France) (M) & Ezzat $1965 \dagger$ & $L$ & $9-42$ & & $6.4 \cdot 10^{-3}$ & 2.62 \\
\hline Homa Lagoon (Izmir, Turkey) & İlkyaz et al. 2006 & $L$ & $7.5-39.5$ & 342 & $1.1 \cdot 10^{-2}$ & 2.93 \\
\hline Stagnone Lagoon (Sicily) & Andaloro 1983 & $L$ & $10-25$ & 423 & $2.0 \cdot 10^{-2}$ & 3.01 \\
\hline Rome area (Italy) & Serbetis $1939 \dagger$ & $L$ & $14-43$ & 40 & $4.9 \cdot 10^{-3}$ & 2.69 \\
\hline Brittany (France) & Thong $1969 \dagger$ & $L$ & $8.1-41.4$ & 127 & $4.2 \cdot 10^{-3}$ & 3.04 \\
\hline Aveiro Lagoon (Portugal) & Arruda et al. 1991 & $L$ & $2-29$ & 3689 & $1.2 \cdot 10^{-2}$ & 2.93 \\
\hline Strymon River estuary, (NW Aegean) & Koutrakis and Tsikliras 2003 & $L$ & $1.7-8.4$ & & $1.0 \cdot 10^{-2}$ & 2.99 \\
\hline Rihios River estuary, (NW Aegean) & Koutrakis and Tsikliras 2003 & $L$ & $2-17.5$ & & $1.2 \cdot 10^{-2}$ & 2.83 \\
\hline
\end{tabular}

$L_{f}=$ fork length, $L s=$ standard length, $L=$ total length, $\mathrm{F}=$ females; $\mathrm{M}=$ males, $n=$ No. of fish; $\dagger$ quoted after Quignard and Farrugio 1981.

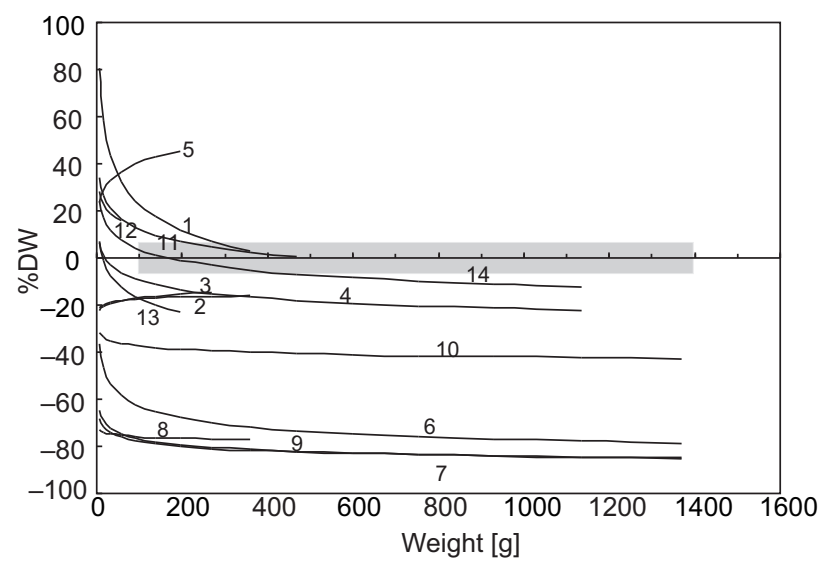

Fig. 5. Comparison of weight percentage difference (\%DW) of Liza aurata from other localities (determined by other authors) with the presently reported study, estimated by length-weight models; The shadowed area indicating the differences which noted in the present study among the sexes and biotopes; $\mathrm{F}=$ females, $\mathrm{M}=$ males, $1=$ Konides et al. 1992, 2 = Giantisi 1985, 3 = Velentza unpublished*, 4 = Dulčić and Kraljević 1997, 5 = Albertini-Berhaut 1978, $6=$ Ezzat $1965 \dagger(\mathrm{M}), 7=$ Ezzat $1965 \dagger(\mathrm{F})$, $8=$ Andaloro $1983,9=$ Serbetis $1939 \dagger, 10=$ Thong $1971 \uparrow, 11=$ Arruda et al. 1991, $12=$ Koutrakis and Tsikliras 2003 (Strymon estuary), $13=$ Koutrakis and Tsikliras 2003 (Rihios estuary), 14 = İlkyaz et al. 2006; $\dagger$ quoted after Quignard and Farrugio 1981

mized within the salinity range from $15 \%$ to $30 \%$ (Shusmin 1990) and it seems that the optimum salinity is the key factor of habitat preference of this species (Cardona 2006). These data support that the relatively high salinity environment of the studied lagoon (Hotos and
Avramidou 1997: about 40\%o) may rebut their high trophic advantage for golden grey mullet. Alternatively, this paradox could be explained by a scenario based on the seasonal migrations of this fish between sea and lagoon (Katselis et al. 2003, 2007). Based to this the lagoon population of species is part of the sea population which migrates in the lagoon during the spring and after shortterm residence in lagoon (some months), returns to sea.

\section{ACKNOWLEDGEMENTS}

The authors wish to thank D. Avramidou for her contribution in the data collection as well as K. Koukou for her comments on the text.

\section{REFERENCES}

Ananiades C. 1984. Aspects of coastal lagoon and pond fishery management problems in Greece. Studies and Reviews, General Fisheries Council for the Mediterranean 61 (2): 478-515.

Albertini-Berhaut J. 1978. Croissance linéaire et pondérale de M. auratus dans le Golfe de Marseille comparee a celle de M. capito. Cybium 3 (4): 51-60.

Anonymous 2001. Meleti diaheirisis tis alieftikis ekmetalefsis ton Ellinikon limnothalasson [Study of management of fishery exploitation of Greek lagoons.] Programma PESCA, ergo 12. Ypourgeio Georgias tis Ellados. Diefthinsi Ydatokalliergeion. Teliki Ekthesi. [Project PESCA, task 12. Ministry of Agriculture of Greece, Direction of Aquaculture. Final report.] [In Greek.]

Anonymous 2002. Fisheries Department, Fishery Information, Data and Statistics Unit. FISH-STAT Plus: Universal software for fishery statistical time series [database on the Internet]. Version 2.3. Food and Agriculture Organization of the United Nations, Rome. 1996-2000. http://www.fao.org/fi/statist/fisoft/ fishplus.asp 
Andaloro F. 1983. Contribution on the knowledge of the age and growth of the Marsala lagoon golden mullet, Liza aurata (Risso, 1810). Rapport de la Commission Internationale Mer Méditerranée 28 (5): 81-82.

Ardizzone G.D., Cataudella S., Rossi R. 1988. Management of coastal lagoon fisheries and aquaculture in Italy. FAO Fisheries Technical paper No. 293.

Arruda L.M., Azevedo J.N., Neto, A.I. 1991. Age and growth of the grey mullet (Pisces, Mugilidae) in Ria de Aveiro (Portugal). Scientia Marina 55 (3): 497-504.

Bagenal T., Tesch F. 1978. Age and growth. Pp. 101-135. In: Bagenal, T.B. (ed.) Methods for assessment of fish production in fresh waters. IBP Handbook No. 3. Blackwell Scientific Publications, Oxford, UK.

Cardona L. 2006. Habitat selection by grey mullets (Osteichthyes: Mugilidae) in Mediterranean estuaries: the role of salinity. Scientia Marina 70 (3): 443-455.

Carlander J.M. 1987. A history of scale and growth studies of North American fresh water fish. Pp. 3-14. In: Summerfelt R.C., Hall G.E. (eds.) Age and growth of fish. Iowa State University Press, Ames IA, USA.

Chen Y., Jackson D.A., Harley H.H. 1992. A comparison of von Bertalanffy and polynomial functions in modeling fish growth data. Canadian Journal of Fisheries and Aquatic Sciences 49 (6): 1228-1235. DOI: 10.1139/f92-138

Dimitriou E., Rogdakis J., Leonardos J., Athanasopoulos A. 1994. He posotiki ke poiotiki synthesi ton alieumaton tis limnothalassas Messolonghiou-Etolikou os deiktis alieftikis diaheirisis. [The qualitative and quantitative composition of the catch of the Messolonghi-Etoliko Lagoon as an index of fisheries management.] Alieftika Nea (155): 82-91. [In Greek.]

Dimitriou E., Katselis G., Koutsikopoulos C. 2000. Katanomi eidon tis alieftikis paragogis tis limnothalassas MessolonghiouEtolikou. [Species diversity of the fishery production of the Messolonghi-Etoliko Lagoon.] Pp. 140-145. In: Praktika tou $6^{\text {ou }}$ Ellinikou Symposiou Okeanografias ke Alieias. [Proceedings of the 6th Hellenic Symposium of Oceanography and Fisheries.] 23-26 May, 2000, Chios, Greece. [In Greek.]

Drake P., Arias A.M., Rodriguez R.B. 1984a. Biology of mullets (Osteichthyes, Mugilidae) in the esteros of San Fernando (Cadix). I. Growth in length and weight. Investigaciones Pesquera 48 (2): 139- 156.

Drake P., Arias A.M., Callego L. 1984b. Biologia de los mugilidos (Osteicththyes, Mugilidae) en los esteros de las salinas de San Fernando (Gadiz). III Hapitos alimentarios y su relacion con la morfometria del aparato digestivo. Investigaciones Pesqueras 48 (2): 337-367.

Dulčić J., Kraljević M. 1997. Weight-length relationships for 40 fish species in the eastern Adriatic (Croatian waters). Fisheries Research 30 (1-2): 169-171. DOI: 10.1016/S0165-7836(97)00555-9

El Zarka S., El Maghraby A.M., Abdel-Hamid K. 1970. Studies on the distribution, growth and abundance of migrating fry juveniles of mullet in a brackish coastal lake (Edku) in the United Arab Republic. Studies and Reviews, General Fisheries Council for the Mediterranean 46: 1-19.

Fazli H., Ghaninejad D., Janbaz A.A., Daryanabard R. 2008. Population ecology parameters and biomass of golden grey mullet (Liza aurata) in Iranian waters of the Caspian Sea. Fisheries Research 93 (1-2): 222-228.

DOI: $10.1016 /$ j.fishres.2008.04.013

Froese R. 2006. Cube law, condition factor and weight-length relationships: history, meta-analysis and recommendations. Journal of Applied Ichthyology 22 (4): 241-253. DOI: $10.1111 / \mathrm{j} .1439-0426.2006 .00805 . \mathrm{x}$

Hotos G. 2003. A study on the scales and age estimation of the golden grey mullet, Liza aurata (Risso, 1810) in the lagoon of Messolonghi (W. Greece). Journal of Applied. Ichthyology 19 (4): 220-228. DOI: $10.1046 / \mathrm{j} .1439-0426.2003 .00481 . \mathrm{x}$

Hotos G., Avramidou D. 1997. A one year water monitoring study of Klisova Lagoon. GeoJournal 41 (1): 15-23.

Hotos G., Avramidou D., Ondrias I. 2000. Reproduction biology of Liza aurata (Risso, 1810), (Pisces: Mugilidae) in the lagoon of Klisova (Messolonghi, W. Greece). Fisheries Research 47 (1): 57-67.

DOI: $10.1016 / \mathrm{S} 0165-7836(99) 00128-9$

İlkyaz T.A., Firat K., Saka Ş., Kinacigil H.T. 2006. Age, Growth and Sex Ratio of Golden Grey Mullet, Liza aurata (Risso, 1810) in Homa Lagoon (İzmir Bay, Aegean Sea). Turkish Journal of Zoology 30: 279-284.

Kapetsky J.M. 1984. Coastal lagoon fisheries around the world: Some perspectives on fishery yields, and other comparative fishery characteristics. Studies and Reviews, General Fisheries Council for the Mediterranean 61: 98-116.

Katselis G., Minos G., Marmagas A., Hotos G., Ondrias I. 1994. Seasonal distribution of Mugilidae fry and juveniles in Messolonghi coastal waters, Western Greece. Bios (Macedonia, Greece) 2: 101-108.

Katselis G., Koutsikopoulos C., Kaspiris P. 2002. Age and growth of the leaping grey mullet, (Liza saliens R.1810) from the Messolonghi-Etoliko Lagoon (western Greece). Mediterranean Marine Science 3 (2): 147-158.

Katselis G., Koutsikopoulos C., Dimitriou E., Rogdakis J. 2003. Spatial and temporal trends in the composition of the fish barriers fisheries production of the Messolonghi-Etoliko Lagoon (western Greek coast). Scientia Marina 67 (4): 501-511.

Katselis G., Koukou K., Dimitriou E., Koutsikopoulos C. 2007. Short-term seaward fish migration in the Messolonghi-Etoliko Lagoons (western Greek coast) in relation to climatic variables and the lunar cycle. Estuarine, Coastal and Shelf Science 73 (3-4): 571-582. DOI: 10.1016/j.ecss.2007.02.010

Katselis G., Koukou K., Moutopoulos D. 2010. Yield per recruit and spawning stock biomass models for the management of four Mugilidae species in Mesolonghi-Aitoliko Lagoon (W. Greece). International Aquatic Research 2: $155-162$.

Kennedy M., Fitzmaurice P. 1969. Age and growth of thicklipped grey mullet Crenimugil labrosus in Irish waters. Journal of Marine Biological Association of the United Kingdom 49 (3): 683-699.

DOI: $10.1017 / \mathrm{S} 002531540003722 \mathrm{X}$

Kesteven G.L. 1960. Manual of field methods in fisheries biology. FAO manuals in Fisheries Sciences, No. 1, FAO, Rome. 
Konides A., Anastasopoulou K., Photis G., Koussouris T., Diapoulis A. 1992. Growth of four Mugilidae species in Western Greek lagoons. 27th European Marine Biology Symposium. 7-11 September 1992, Trinity College, Dublin, Ireland.

Kotsonias G. 1984. The Messolonghi-Etolico Lagoon of Greece. Socio-economic and ecological interactions of cooperative and independent fishermen. Studies and Reviews, General Fisheries Council for the Mediterranean 61 (2): 521-528.

Koutrakis E.T., Sinis A.I. 1994. Growth analysis of grey mullets (Pisces, Mugilidae) as related to age and site. Israel Journal of Zoology 40 (1): 37-53.

Koutrakis E.T., Sinis A. I., Economidis P.S. 1994. Seasonal occurrence, abundance and size distribution of grey mullet fry (Pisces, Mugilidae), in Porto-Lagos Lagoon and Lake Vistonis (Aegean Sea, Greece). Israeli Journal Aquaculture (Bamidgeh) 46 (4): 182-196.

Koutrakis E.T., Tsikliras A.C. 2003. Length-weight relationships of fishes from three northern Aegean estuarine systems (Greece). Journal of Applied Ichthyology 19 (4): 258-260. DOI: 10.1046/j.1439-0426.2003.00456.x

Kraljević M., Dulčić J. 1996. Age, growth and mortality of the golden grey mullet Liza aurata (Risso, 1810) in the eastern Adriatic. Archive of Fishery and Marine Research 44 (1/2): 69-80.

Minos G., Katselis G., Ondrias I., Harrison I.J. 2002. Use of melanophore patterns on the ventral side of the head to identify fry of grey mullet (Teleostei: Mugilidae). Israeli Journal Aquaculture (Bamidgeh) 54 (1): 12-26.

Modrusan Z., Teskeredzic E., Jukic S. 1988: Biology and ecology of Mugilidae species on the Eastern Adriatic coast (Šibenik Bay). FAO Fisheries Report (394): 159-167.

Brusle J. 1981. Sexuality and biology of reproduction in grey mullets. Pp. 99-154. In: Oren O.H. (ed.) Aquaculture of grey mullets. Cambridge University Press, Cambridge, UK.
Pauly D., Munro J. 1984. Once more on growth comparison in fish and invertebrates. Fishbyte 2 (1): 21.

Pearce F., Crivelli A.J. 1994. Characteristics of Mediterranean wetlands. MedWet Publications, Tour du Valat, Arles, France.

Peja N., Vaso A., Miho A., Rakaj N., Crivelli A.J. 1996. Characteristics of Albanian lagoons and their fisheries. Fisheries Research 27 (4): 115-125.

DOI: $10.1016 / 0165-7836(95) 00467-X$

Reay P.J. 1987. A British population of the grey mullet, Liza aurata (Teleostei, Mugilidae). Journal of the Marine Biological Association of the United Kingdom 67 (1): 1-10. DOI: $10.1017 / \mathrm{S} 002531540002631 \mathrm{X}$

Quignard J.P., Farrugio H. 1981. Age and growth of grey mullets. Pp. 155-184. In: Oren O.H. (ed.) Aquaculture of grey mullets. Cambridge University Press, Cambridge, UK.

Shusmin A.G. 1990. Effects of changes of salinity on survival, oxygen threshold and level of standard metabolism of young of the golden mullet (Liza aurata). Journal of Ichthyology 30: $139-145$.

Thomson J.M. 1990 Mugilidae. Pp. 855-859. In: Quero J.C., Hureau J.C., Karrer C., Post A., Saldanha L. (eds.) Check-list of the fishes of the eastern tropical Atlantic (CLOFETA). Vol. 2. JNICT, Lisbon; SEI, Paris; and UNESCO, Paris.

Zar J.H. 1984: Biostatistical Analysis. Prentice-Hall, Englewood Cliffs, NJ, USA.

Received: 12 November 2010 Accepted: 6 May 2011 Published electronically: 30 September 2011 